Article

\title{
Coordination Behavior of Bis-Imidazole and Various Carboxylate Ligands towards Zn(II) and Cd(II) Ions: Synthesis, Structure, and Photoluminescence Study
}

\author{
Kang Liu ${ }^{\mathbb{D}}$, Liming Deng, Yaowen Zhang, Shaoshao Jiao, Yanling Geng and Lei Wang * \\ Key Laboratory of Eco-chemical Engineering, Ministry of Education, Laboratory of Inorganic Synthesis and \\ Applied Chemistry, College of Chemistry and Molecular Engineering, Qingdao University of Science and \\ Technology, Qingdao 266042, China; liukang82@126.com (K.L.); ccedenglm@163.com (L.D.); \\ sw_zhangyw@163.com (Y.Z.); jiaoss0309@163.com (S.J.); ylgeng@qust.edu.cn (Y.G.) \\ * Correspondence: inorchemw1@126.com; Tel.: +86-532-840-22681
}

Received: 3 May 2018; Accepted: 24 May 2018; Published: 25 May 2018

\begin{abstract}
Four coordination polymers (CPs) based on bis-imidazole ligands (1,2-bimb and 1,2-bmimb), namely, $\left\{[\mathrm{Zn}(1,2-\text {-bimb })(2,5 \text {-dtpa })] \mathrm{H}_{2} \mathrm{O}\right\}_{\mathrm{n}}(\mathbf{1}),\left\{\left[\mathrm{Cd}_{2}(1,2-\text {-bimb })_{2}(5-\text {-hipa })_{2}\right] 2 \mathrm{H}_{2} \mathrm{O}\right\}$ (2), $\left\{\mathrm{Zn}_{2}(1,2-\mathrm{bimb})(\mathrm{L})\left(\mathrm{CH}_{3} \mathrm{COO}\right) \mathrm{DMF} \cdot 2 \mathrm{H}_{2} \mathrm{O}\right\}_{\mathrm{n}}(3)$ and $\{\mathrm{Cd}(1,2-\mathrm{bmimb})(3-\mathrm{npa})\}_{\mathrm{n}}(4)$, have been synthesized by solvothermal reactions (1,2-bimb $=1,2$-bis $((1 H$-imidazol-1-yl $)$ methyl)benzene, 1,2 -bmimb $=$ 1,2-bis((2-methyl-1H-imidazol-1-yl)methyl)benzene, 2,5- $\mathrm{H}_{2} \mathrm{dtpa}=$ 2,5-diaminoterephthalic acid, 5- $\mathrm{H}_{2}$ hipa $=5$-hydroxyisophthalic acid, $\mathrm{H}_{3} \mathrm{~L}=3,3^{\prime}, 3^{\prime \prime}$-(2,4,6-trioxo-1,3,5-triazinane-1,3,5-triyl)tripropanoic acid, 3- $\mathrm{H}_{2}$ npa $=3$-nitrophthalic acid) and structurally verified by single-crystal $\mathrm{X}$-ray diffraction analyses and further characterized by powder X-ray diffraction (PXRD), elemental analyses and infrared spectroscopy (IR). Complex 1 and 2 show a dinuclear 2D layered structure. Complex 4 exhibits a two-dimensional network consisting of $[\mathrm{Cd}(3-\mathrm{npa})]_{\mathrm{n}}$ and $[\mathrm{Cd}(1,2-\mathrm{bmimb})]_{\mathrm{n}}$ chains. Both $\mathbf{1 , 2}$ and 4 display a 4-connected sql topology sheet, which can be further expanded into a 3D supramolecular network through $\pi \cdots \pi$ interaction between layers. Complex 3 features a 3D $(3,6)$-connected $\left\{4^{2} \cdot 6\right\} \cdot\left\{4^{4} \cdot 6^{10} \cdot 8\right\}-3,6 \mathrm{~T} 24$ topology structure consisting of 2D bilayers. Structural comparison reveals that it is not only the substituents at different positions of ancillary ligands and the primary bis(imidazole) linkers that play crucial roles in the control of the final structures. Besides, the photoluminescence properties of 1-4 have been investigated in the solid state at room temperature.
\end{abstract}

Keywords: coordination polymers; crystal structure; X-ray diffraction; photoluminescence properties

\section{Introduction}

The design and synthesis of new coordination polymers (CPs) have attracted enormous attention in recent years, not only for their intriguing structures and diverse topologies, but also for their potential applications in gas adsorption and separation, catalysis, magnetism, luminescent sensor and so on [1-6]. Among them, the luminescent properties of coordination polymers are widely studied. As we all know, the organic ligands often contain aromatic rings or conjugated groups that are subject to excitation, giving rise to photoluminescence (PL) upon irradiation. Moreover, the metal center also contributes to optical emission, such as lanthanides and inorganic cluster. Utilizing their emission properties, various types of sensors are being developed. Luminescent sensors for detecting cations, anions, small molecules, explosives and temperature have been applied to various fields $[7,8]$. Many researchers attempted to control the self-assembly process of CPs and expected to synthesize precise structures with specific properties. However, it is difficult to design and predict a new $\mathrm{CP}$ structure because of various factors, such as solvents, $\mathrm{pH}$ values, temperature, template, the structural 
characteristics of organic ligands, the nature of the metal ions, the counterions and other various experimental conditions [9-13]. Among these various factors, the selection of suitable organic ligands is more effective and is a prerequisite for controlling the synthesis of novel coordination materials [14].

An effective way to carry out the reaction is to use mixed ligands such as carboxylic acid ligands and N-containing ligands in the same system [15]. More and more CPs from 1D to 3D have already been synthesized by using polyimidazole ligands as spacers, such as 1,3,5-tris(1-imidazolyl)-benzene, 1,4-bis(imidazolyl)benzene in combination with various polycarboxylate ligands as linkers [16]. Furthermore, we have been striving to synthesize systematically mixed-ligand CPs by adjusting the carboxylic acid chain with different substituents and the flexible/rigid properties of N-containing ligands, and to explain the topological relationships of the CPs $[17,18]$. Previous studies showed that carboxylate auxiliary ligands can provide cooperative coordination together with the $\mathrm{N}$-containing ligands to meet the requirements of the coordination geometries of the metal ions in the assembly process. Although many bis-imidazol ligands and different poly-acids have been widely used to synthesize new coordination polymers [19-25], there are relatively rare in exploring the effect of the introduction of substituents and different carboxylic acid positions on the structure.

To further expand our research the mixed-ligand CPs, 1,2-bis(imidazol-1-ylmethyl)benzene) (1,2-bimb) and 1,2-bis((2-methyl-1H-imidazol-1-yl)methyl)benzene (1,2-bmimb) is chosen as the primary ligand, owing to its flexible coordination ability. Meanwhile, carboxyl groups of different substitution positions and different substituents dicarboxylate ligands have been introduced into the system to react with transition metal. Herein, four mixed-ligand CPs have been successfully synthesized (Scheme 1), namely $\left\{[\mathrm{Zn}(1,2-\mathrm{bimb})(2,5-\mathrm{dtpa})] \cdot \mathrm{H}_{2} \mathrm{O}\right\}_{\mathrm{n}}$ (1), $\left\{\left[\mathrm{Cd}_{2}(1,2-\text {-bimb })_{2}(5-\text { hipa })_{2}\right] \cdot 2 \mathrm{H}_{2} \mathrm{O}\right\}_{\mathrm{n}}(2),\left\{\mathrm{Zn}_{2}(1,2-\text {-bimb })(\mathrm{L})\left(\mathrm{CH}_{3} \mathrm{COO}\right) \cdot \mathrm{DMF}_{2} \mathrm{H}_{2} \mathrm{O}\right\}_{\mathrm{n}} \quad$ (3), and $\{\mathrm{Cd}(1,2-\mathrm{bmimb})(3-\mathrm{npa})\}_{\mathrm{n}}(4)$. Their synthesis crystal structures, topologies, thermal stabilities, photoluminescence properties are reported in this paper.

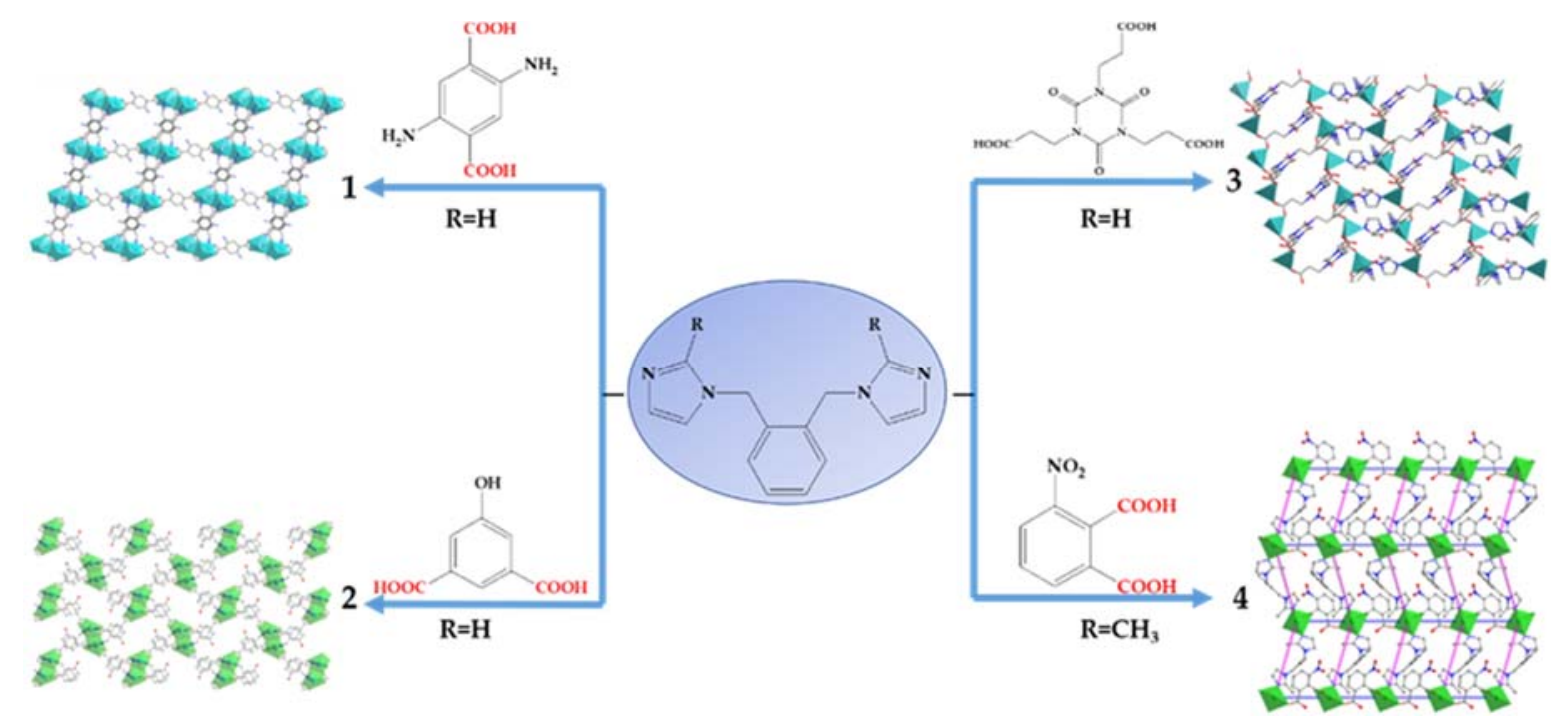

Scheme 1. Structures drawing of primary and auxiliary ligand, as well as introduction to self-assembly of complexes 1-4.

\section{Materials and Methods}

\subsection{Materials and Physical Measurements}

The ligands 1,2-bimb and 1,2-bmimb were prepared according to reported methods [26,27]. The auxiliary ligands and other materials were purchased from commercial sources and without further purification. 
The FT-IR spectra were measured on a NEXUS 670 FTIR spectrometer (Thermo Nicolet Corporation, Madison, WI, USA) in the range of $600-4000 \mathrm{~cm}^{-1}$ using $\mathrm{KBr}$ pellets. Elemental analyses (EA) were carried out on a CE instruments EA 1110 elemental analyzer (Carlo-Erba Corporation, Sandwich, Italy). TGA were carried out on an SDT Q600 instrument (TA Instruments, New Castle, DE, USA) at a heating rate of $5{ }^{\circ} \mathrm{C}$ under a $\mathrm{N}_{2}$ atmosphere. The powder X-ray diffraction (PXRD) spectra of complexes 1-4 were measured on a Rigaku D/Max-2500 diffractometer (Rigaku Corporation, Tokyo, Japan) with $\mathrm{Cu}-\mathrm{K} \alpha$ radiation. Fluorescence spectra were obtained by a Hitachi F-4500 fluorescence spectrophotometer (Hitachi Limited, Tokyo, Japan) at room temperature.

\subsection{Methods}

\subsection{1. $\left\{[\mathrm{Zn}(1,2-\mathrm{Bimb})(2,5-\mathrm{dtpa})] \cdot \mathrm{H}_{2} \mathrm{O}\right\}_{\mathrm{n}}(\mathbf{1})$}

A mixture of $\mathrm{Zn}\left(\mathrm{NO}_{3}\right)_{2} \cdot 6 \mathrm{H}_{2} \mathrm{O}(0.2 \mathrm{mmol}, 0.0544 \mathrm{~g}), 1,2-\mathrm{bimb}(0.1 \mathrm{mmol}, 0.0238 \mathrm{~g}), 2,5-\mathrm{H}_{2} \mathrm{dtpa}$ (0.1 mmol, $0.0196 \mathrm{~g}), \mathrm{KOH}$ (0.1 mmol, $0.0056 \mathrm{~g}), \mathrm{N}, \mathrm{N}^{\prime}$-dimethylformamide (DMF) (5 mL), and $\mathrm{H}_{2} \mathrm{O}$ $(5 \mathrm{~mL})$ was added in a $18 \mathrm{~mL}$ Teflon-lined stainless steel vessel, which was heated to $120^{\circ} \mathrm{C}$ for $72 \mathrm{~h}$ and then cooled to room temperature at a rate of $5{ }^{\circ} \mathrm{C} / \mathrm{h}$. Colorless block crystals of $\mathbf{1}$ were obtained in $56 \%$ yield (based on 1,2-bimb), washed with acetone, and dried in air. Anal. Calcd. for $\mathrm{C}_{22} \mathrm{H}_{22} \mathrm{~N}_{6} \mathrm{O}_{5} \mathrm{Zn}$ (515.85): C, 51.26; H, 4.26; N, 16.28. Found: C, 51.22; H, 4.22; N, 16.23. IR (KBr pettlet, $\left.\mathrm{cm}^{-1}\right): 3436(\mathrm{~m})$, $3367(\mathrm{~m}), 3234(\mathrm{~m}), 2341(\mathrm{w}), 1621(\mathrm{~s}), 1552(\mathrm{~s}), 1527(\mathrm{~s}), 1430(\mathrm{~s}), 1385(\mathrm{~s}), 1326(\mathrm{~m}), 1308(\mathrm{~m}), 1255(\mathrm{~m})$, $1109(\mathrm{w}), 1054(\mathrm{~m}), 1011(\mathrm{w}), 942(\mathrm{w}), 897(\mathrm{w}), 851(\mathrm{~m}), 830(\mathrm{w}), 769(\mathrm{w}), 739(\mathrm{~m}), 645(\mathrm{~m}), 623(\mathrm{w}), 574$ $(\mathrm{w}), 525(\mathrm{~m})$.

\subsection{2. $\left\{\left[\mathrm{Cd}_{2}(1,2-\mathrm{Bimb})_{2}(5-\text { hipa })_{2}\right] \cdot 2 \mathrm{H}_{2} \mathrm{O}\right\}$ n (2)}

The same synthetic procedure as for complex 1 was used expect that 2,5- $\mathrm{H}_{2} \mathrm{dtpa}$ was replaced by $5-\mathrm{H}_{2}$ hipa. Colorless block crystals of 2 were obtained. Then, it was washed through ethanol and deionized water and dried in air. Yield $49 \%$ based on 1,2-bimb. Anal. Calcd. for $\mathrm{C}_{44} \mathrm{H}_{40} \mathrm{Cd}_{2} \mathrm{~N}_{8} \mathrm{O}_{12}$ (1097.66): C, 48.10; H, 3.64; N, 10.20. Found: C, 48.05; H, 3.62; N, 10.15. IR (KBr pettlet, $\left.\mathrm{cm}^{-1}\right)$ : 3588 (s), 3287 (s), 3109 (s), 2567 (s), 1709 (s), 1624 (s), 1566 (s), 1512 (s), 1383 (s), 1286 (s), 1235(s), 1104 (m), 1083 (s), $966(\mathrm{w}), 823(\mathrm{w}), 776(\mathrm{~m}), 721(\mathrm{~m}), 661(\mathrm{w})$.

\subsection{3. $\left\{\mathrm{Zn}_{2}(1,2-\mathrm{Bimb})(\mathrm{L})\left(\mathrm{CH}_{3} \mathrm{COO}\right) \cdot \mathrm{DMF} \cdot 2 \mathrm{H}_{2} \mathrm{O}\right\}_{\mathrm{n}}(3)$}

A mixture of $\mathrm{Zn}\left(\mathrm{CH}_{3} \mathrm{COO}\right)_{2} \cdot 2 \mathrm{H}_{2} \mathrm{O}(0.2 \mathrm{mmol}, 0.0438 \mathrm{~g}), 1,2$-bimb $(0.1 \mathrm{mmol}, 0.0238 \mathrm{~g}), \mathrm{H}_{3} \mathrm{~L}$ (0.1 mmol, $0.0345 \mathrm{~g}), \mathrm{KOH}(0.2 \mathrm{mmol} 0.0112 \mathrm{~g}), N, N^{\prime}$-dimethylformamide (DMF) ( $5 \mathrm{~mL}$ ), and $\mathrm{H}_{2} \mathrm{O}$ $(5 \mathrm{~mL})$ was added in a $18 \mathrm{~mL}$ Teflon-lined stainless steel vessel, which was heated to $120^{\circ} \mathrm{C}$ for $72 \mathrm{~h}$ and then cooled to room temperature at a rate of $5{ }^{\circ} \mathrm{C} / \mathrm{h}$. Colorless block crystals of 3 were obtained in $57 \%$ yield (based on 1,2-bimb), washed with acetone, and dried in air. Anal. Calcd. for $\mathrm{C}_{31} \mathrm{H}_{40} \mathrm{~N}_{8} \mathrm{O}_{14} \mathrm{Zn}_{2}$ (879.45): C, 42.30; H, 4.55; N, 12.73. Found: C, 42.22; H, 4.53; N, 12.67. IR (KBr pettlet, $\left.\mathrm{cm}^{-1}\right): 3238$ (s), $3100(\mathrm{~s}), 2645$ (s), 1732 (s), 1647 (s), 1547 (s), 1512 (s), 1388 (s), $1144(\mathrm{~s}), 1077$ (s), 946 (w), 823 (w), 766 (m), $711(\mathrm{~m}), 641(\mathrm{w})$.

\subsection{4. $\{\mathrm{Cd}(1,2-\mathrm{Bmimb})(3-\mathrm{npa})\}_{\mathrm{n}}(4)$}

A mixture of $\mathrm{Cd}\left(\mathrm{NO}_{3}\right)_{2} \cdot 6 \mathrm{H}_{2} \mathrm{O}(0.2 \mathrm{mmol}, 0.0492 \mathrm{~g}), 1,2-\mathrm{bmimb}(0.1 \mathrm{mmol}, 0.0238 \mathrm{~g}), 3-\mathrm{H}_{2} \mathrm{npa}$ ( $0.1 \mathrm{mmol}, 0.0211 \mathrm{~g}), \mathrm{KOH}(0.1 \mathrm{mmol}, 0.0056 \mathrm{~g}), \mathrm{N}, \mathrm{N}^{\prime}$-dimethylformamide (DMF) ( $5 \mathrm{~mL}$ ), and $\mathrm{H}_{2} \mathrm{O}$ $(5 \mathrm{~mL})$ was added in a $18 \mathrm{~mL}$ Teflon-lined stainless steel vessel, which was heated to $120^{\circ} \mathrm{C}$ for $72 \mathrm{~h}$ and then cooled to room temperature at a rate of $5{ }^{\circ} \mathrm{C} / \mathrm{h}$. Colorless block crystals of 4 were obtained in 50\% yield (based on 1,2-bimb), washed with deionized water, and dried in air. Anal. Calcd. for $\mathrm{C}_{24} \mathrm{H}_{21} \mathrm{CdN}_{5} \mathrm{O}_{6}$ (587.86): $\mathrm{C}, 49.06 ; \mathrm{H}, 3.57 ; \mathrm{N}, 11.92$. Found: $\mathrm{C}, 48.68 ; \mathrm{H}, 3.42 ; \mathrm{N}, 12.03$. IR (KBr pettlet, $\left.\mathrm{cm}^{-1}\right)$ : $3422(\mathrm{~m}), 1612(\mathrm{~s}), 1517(\mathrm{~s}), 1384(\mathrm{~s}), 1352(\mathrm{~s}), 1268(\mathrm{w}), 1112(\mathrm{~s}), 1058(\mathrm{~m}), 944(\mathrm{~m}), 843(\mathrm{~m}), 822$ (m), $740(\mathrm{~m}), 655(\mathrm{w}), 609(\mathrm{w})$. 


\subsection{X-ray Crystallography}

Diffraction intensity date was carried out on a Siemens SMART diffractometer equipped with a CCD area detector using Mo-K $\alpha$ monochromatic radiation $(\lambda=0.71073 \AA$ Siemens Limited, Berlin, Germany). The absorption correction was based on multiple and symmetry-equivalent reflections in the date set using the program SADABS (Version 2.03) [28]. The structures were solved by direct methods with SHELXS-97 (Version 6.10) and refined with the full-matrix least-squares technique using the SHELXS-97 program [29]. All non-hydrogen atoms were refined anisotropically [30]. The hydrogen atoms attached to carbon and oxygen atoms were included in the structure factor calculations. Crystallographic date for complexes 1-4 are summarized in Table 1 and selected bond lengths and angles are listed in Tables S1-S4.

Table 1. Crystallographic date and structure refinement results for complexes 1-4.

\begin{tabular}{ccccc}
\hline Complex & $\mathbf{1}$ & $\mathbf{2}$ & $\mathbf{3}$ & $\mathbf{4}$ \\
\hline Empirical formula & $\mathrm{C}_{22} \mathrm{H}_{22} \mathrm{~N}_{6} \mathrm{O}_{5} \mathrm{Zn}$ & $\mathrm{C}_{44} \mathrm{H}_{40} \mathrm{~N}_{8} \mathrm{O}_{12} \mathrm{Cd}_{2}$ & $\mathrm{C}_{31} \mathrm{H}_{40} \mathrm{~N}_{8} \mathrm{O}_{14} \mathrm{Zn}_{2}$ & $\mathrm{C}_{24} \mathrm{H}_{21} \mathrm{~N}_{5} \mathrm{O}_{6} \mathrm{Cd}$ \\
Formula weight & 515.85 & 1097.66 & 879.45 & 587.86 \\
$\mathrm{~T} / \mathrm{K}$ & $293(2)$ & $293(2)$ & $293(2)$ & $293(2)$ \\
Crystal system & triclinic & monoclinic & triclinic & monoclinic \\
Space group & $P 1$ & $P 22_{1} / \mathrm{c}$ & $P 1$ & $P 21 / n$ \\
$\mathrm{a} / \AA$ & $10.0751(6)$ & $14.631(4)$ & $9.3223(5)$ & $7.464(6)$ \\
$\mathrm{b} / \AA$ & $10.2040(5)$ & $18.462(5)$ & $13.1795(5)$ & $19.816(15)$ \\
$\mathrm{c} / \AA$ & $11.4148(5)$ & $15.946(4)$ & $16.5396(10)$ & $16.031(12)$ \\
$\alpha /{ }^{\circ}$ & $100.519(4)$ & 90 & $92.650(4)$ & 90 \\
$\beta /{ }^{\circ}$ & $95.060(4)$ & $98.955(4)$ & $105.391(5)$ & 103.46 \\
$\gamma /{ }^{\circ}$ & $106.233(5)$ & 90 & $102.938(4)$ & 90 \\
$\mathrm{~V} / \AA^{3}$ & $1095.68(10)$ & $4255(2)$ & $1897.38(18)$ & $2306(3)$ \\
$\mathrm{Z}$ & 2 & 4 & 2 & 4 \\
$\mathrm{Dc} / \mathrm{Mg}^{-} \mathrm{cm}^{-3}$ & 1.564 & 1.714 & 1.539 & 1.693 \\
$\mu / \mathrm{mm}^{-1}$ & 1.169 & 1.075 & 1.340 & 1.000 \\
$\mathrm{~F}(000)$ & 532 & 2208.0 & 908 & 1184.0 \\
$\mathrm{R}(\mathrm{int})$ & $7339 / 3860$ & $21,299 / 7423$ & $13,632 / 6669$ & $11,646 / 4045$ \\
$\mathrm{GOF}$ on $\mathrm{F}^{2}$ & 0.0279 & 0.0632 & 0.0366 & 0.1034 \\
Reflections collected $/$ independent & 1.087 & 1.060 & 1.026 & 1.073 \\
Final $\mathrm{R}$ indexes $\mathrm{R}_{1}\left(\mathrm{wR} \mathrm{R}_{2}\right)[\mathrm{I} \geq 2 \sigma(\mathrm{I})]$ & $0.0882(0.2545)$ & $0.0634(0.1799)$ & $0.0432(0.0839)$ & $0.0371(0.0919)$ \\
Final $\mathrm{R}$ indexes $\mathrm{R}_{1}\left(\mathrm{wR} \mathrm{R}_{2}\right)(\mathrm{all}$ data) & $0.1035(0.2773)$ & $0.0861(0.1916)$ & $0.0700(0.0956)$ & $0.0433(0.0965)$ \\
Largest diff. peak/hole/e $\AA^{-3}$ & $1.33 /-0.87$ & $2.17 /-1.87$ & $0.37 /-0.50$ & $0.56 /-1.27$ \\
\hline
\end{tabular}

CCDC (1839112 for 1, 1839113 for 2, 1839114 for 3, 1840894 for 4) contains the supplementary crystallographic for this paper. There data can be obtained free of charge via http://www.ccdc. cam.ac.uk/conts/retrieving.html (or from the CCDC, 12 Union Road, Cambridge CB2 1EZ, UK; Fax: +44-1223-336033; E-mail: deposit@ccdc.cam.ac.uk).

\section{Results and Discussion}

\subsection{Crystal Structures of $\left\{[\mathrm{Zn}(1,2-\mathrm{Bimb})(2,5-\mathrm{dtpa})] \cdot \mathrm{H}_{2} \mathrm{O} \ln (\mathbf{1})\right.$}

Single-crystal X-ray diffraction analysis reveals that complex 1 crystallizes in the triclinic with space group $P 1$. The asymmetric unit consists of one crystallographically independent $\mathrm{Zn}$ II ion, one 1,2-bimb ligand, one 2,5-dtpa anion and one lattice water molecule. As shown in Figure 1a, each $\mathrm{Zn}{ }^{\mathrm{II}}$ ion located in a distorted $\left[\mathrm{ZnO}_{5} \mathrm{~N}_{2}\right]$ decahedron geometry, surrounded by five oxygen atoms of three 2,5-dtpa anions, two nitrogen atoms from two 1,2-bimb ligands. The bond lengths around the $\mathrm{Zn}^{\mathrm{II}}$ ions are in the range of 2.186(5)-2.566(4) $\AA$. There are two coordination modes of 2,5-dtpa anions in complex 1 . Both the two carboxylate group in 2.5-dtpa (mode I) anion ligated to four $\mathrm{Zn}^{\mathrm{II}}$ ions in $\mu_{2}-\eta^{2}: \eta^{1}$ coordination mode, while the carboxylate groups in another 2,5-dtpa (mode II) adopt $\mu_{1}-\eta^{1}: \eta^{1}$ coordination mode (Figure $1 \mathrm{~b}$ ). Two adjacent zinc atoms are connected by two oxygen atoms $(\mathrm{O} 1, \mathrm{O} 2)$ from 2,5-dtpa anion forming one binuclear $\mathrm{Zn}$ cluster. Further, the structure is built around 
centrosymmetric $\mathrm{Zn}_{2} \mathrm{O}_{2}$ dimers with the $\mathrm{Zn} \cdots \mathrm{Zn}$ distances of 3.7786(9) $\AA$. Then, the 2,5-dtpa anions and 1,2-bimb ligands further expanded the $\mathrm{Zn}_{2} \mathrm{O}_{2}$ dimers into a 2D layer (Figure 1c). As shown in Figure $1 \mathrm{~d}$, the $\pi \ldots \pi$ interactions between the benzene rings of 2,5-dtpa and 1,2-bimd ligands with distance of $3.753 \AA$ play important role in the formation of three-dimensional network structure.

Topology analysis reveals that complex $\mathbf{1}$ is a $2 \mathrm{D}$ interpenetrated 4-connected sql net with point symbol of $\left\{4^{4} \cdot 6^{2}\right\}$ by regarding the binuclear Zn cluster as 4-connected node, 2,5-dtpa anion and 1,2-bimb ligand as a 2-connected node, respectively (Figure 1e).

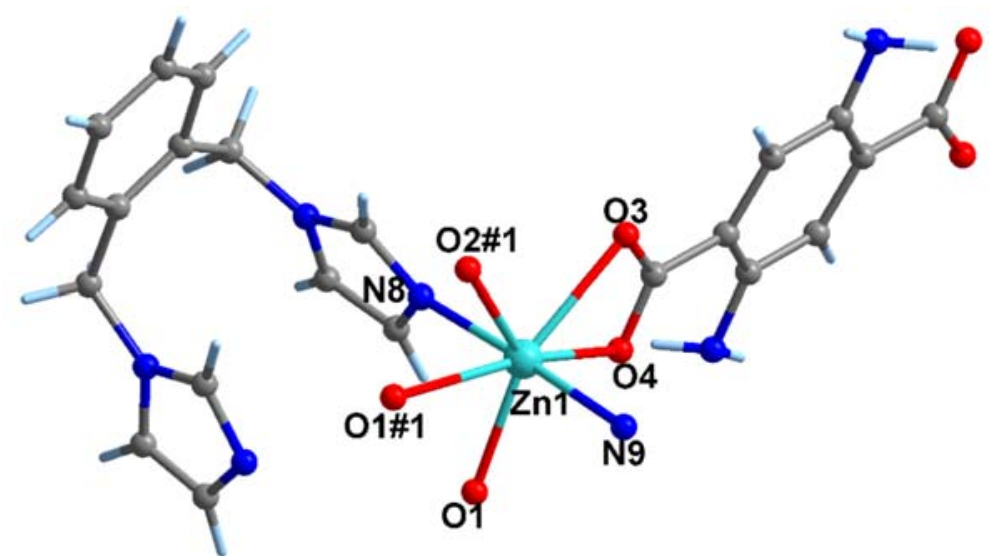

(a)

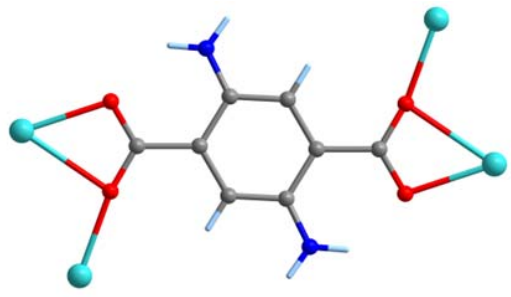

Mode I

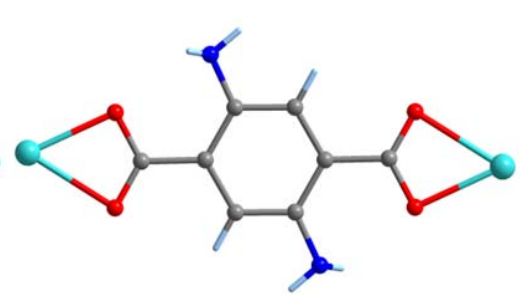

Mode II

(b)

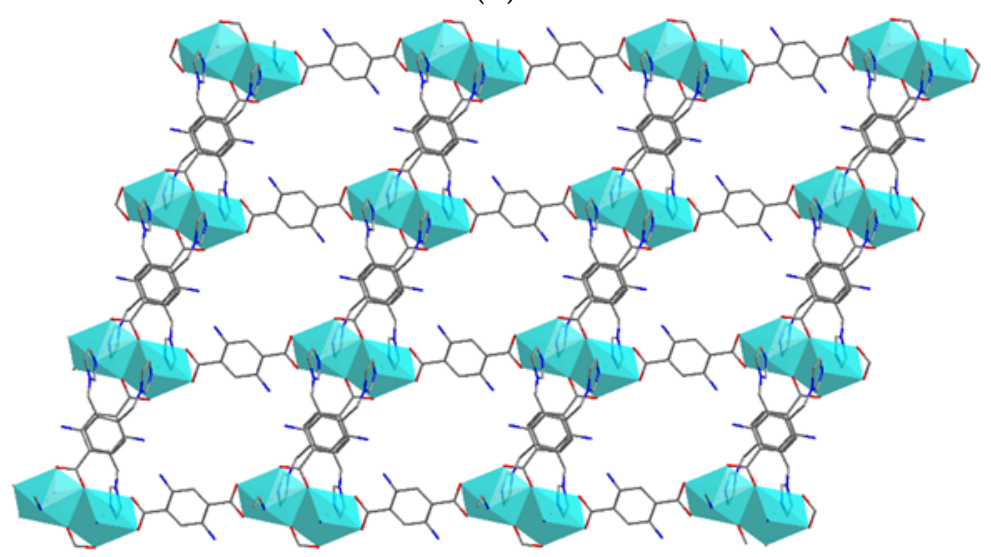

(c)

Figure 1. Cont. 


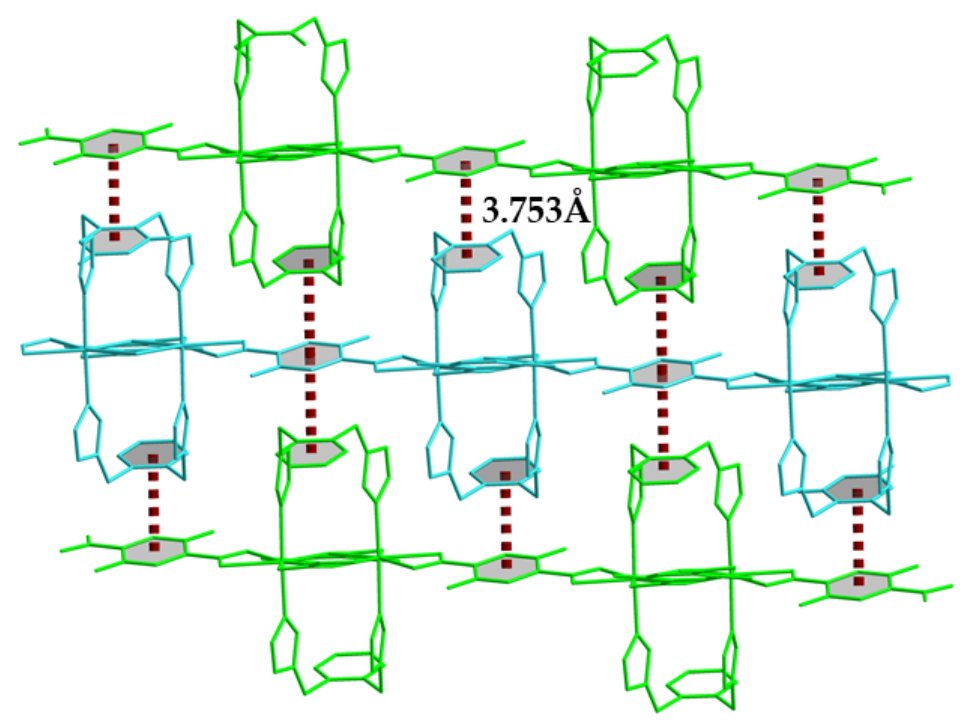

(d)
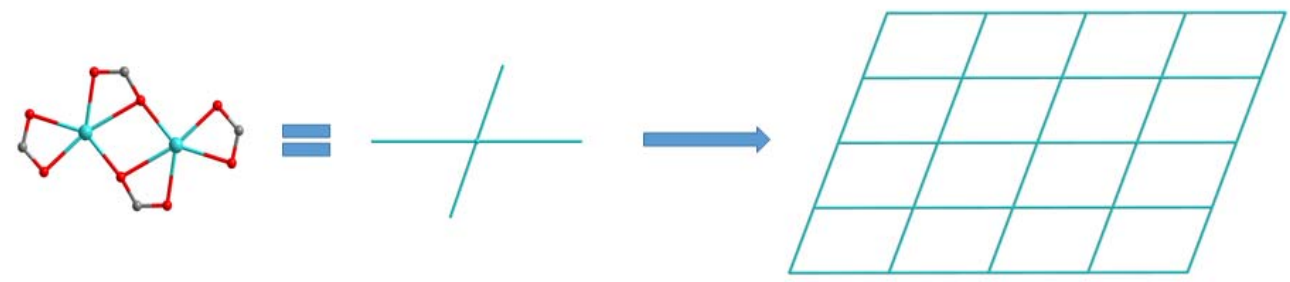

(e)

Figure 1. (a) The coordination environment of the $\mathrm{Zn}^{\mathrm{II}}$ ion in complex $\mathbf{1}$ (symmetry codes: \#1 - X, $-\mathrm{Y},-\mathrm{Z}$ ); (b) Two coordination modes of 2,5-dtpa ligand; (c) The 2D layered structure; (d) The 3D supramolecular structure by $\pi \ldots \pi$ interactions; (e) The sql topology of the complex 1 (cyan, Zn; blue, $\mathrm{N}$; red, O; gray, C; light blue, $\mathrm{H}$ ).

\subsection{Crystal Structures of $\left\{\left[C d_{2}(1,2-B i m b)_{2}(5-\text { hipa })_{2}\right] \cdot 2 \mathrm{H}_{2} \mathrm{O}\right\}_{n}(2)$}

Complex 2 crystallizes in the monoclinic space group $P 2_{1} / c$. The asymmetric unit consists of two $\mathrm{Cd}^{\mathrm{II}}$ ions, two 1,2-bimb ligands, two 5-hipa anions and two lattice water molecules. As shown in Figure 2a, Cd1 locates at the crystallographic center and is seven-coordinated by five carboxylate oxygen atoms from three 5-hipa anions, and four imidazole nitrogen atoms from two distinct 1,2-bimb ligands to give a $\left\{\mathrm{CdO}_{5} \mathrm{~N}_{2}\right\}$ decahedron coordination geometry. $\mathrm{Cd} 2$ is similar to that of $\mathrm{Cd} 1$. Two $\mathrm{Cd}$ atoms are connected by two carboxylate oxygen atoms $(\mathrm{O} 7, \mathrm{O} 8)$ of 5-hipa anion forming one binuclear $\mathrm{Cd}$ cluster with the $\mathrm{Cd}$... Cd distances of 3.8562(12) $\AA$. The $\mathrm{Cd}-\mathrm{O} / \mathrm{N}$ bond lengths are in the range of 2.203(7)-2.794(6) $\AA$. The bond angles around $\mathrm{Cd}^{\mathrm{II}}$ ion are in the range of $49.77(17)^{\circ}-171.6(3)^{\circ}$. In complex 2, the 5-hipa anion adopt a $\mu^{3}-\eta^{1}: \eta^{2}: \eta^{1}: \eta^{1}$ coordination mode (Figure 2b). The binuclear Cd cluster connected by 5-hipa anions and 1,2-bimb ligands to form a 2D layer extended along c-axis (Figure 2c). The $\pi \cdots \pi$ interactions between the benzene ring of 5-hipa anions and 1,2-bimb ligands with a separation of $3.930 \AA$ play a critical role in the formation of 3D supramolecular framework (Figure 2d).

Topologically, if the binuclear Cd cluster is viewed as four-connected nodes and each 1,2-bimb or 5-hipa serves as a two-connected spacer, complex $\mathbf{2}$ can be simplified as a 2D sql topology with a point symbol of $\left\{4^{4} \cdot 6^{2}\right\}$ (Figure 2e). 


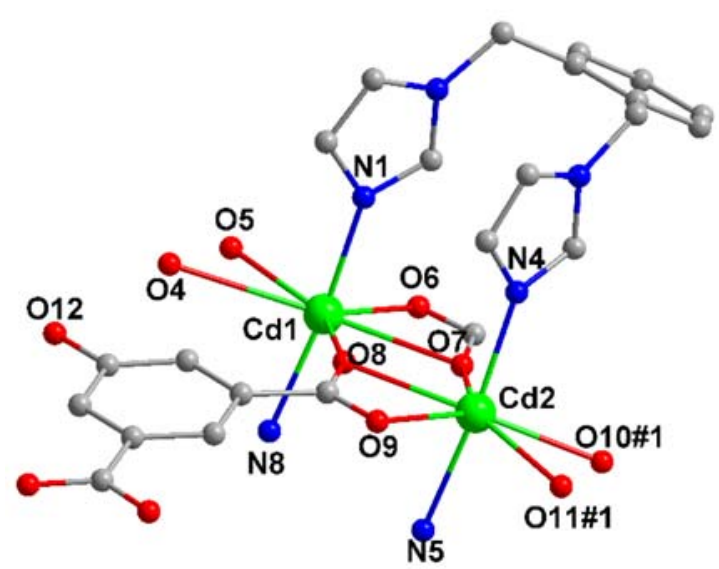

(a)

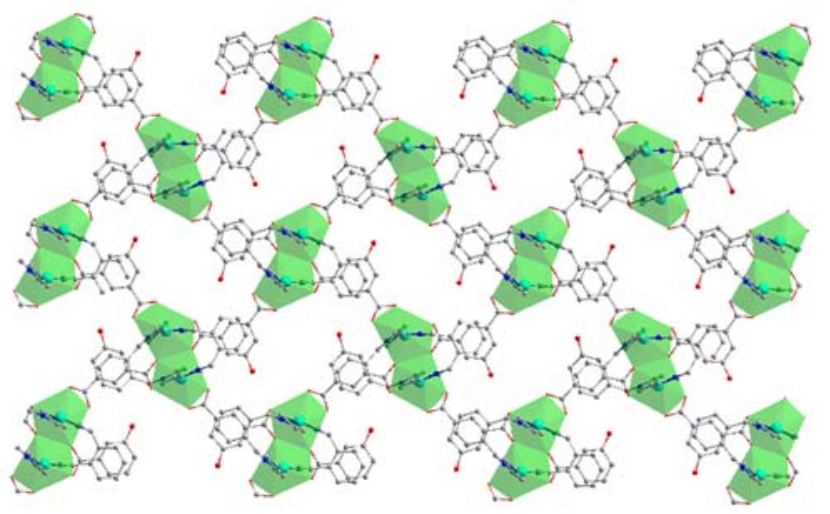

(c)

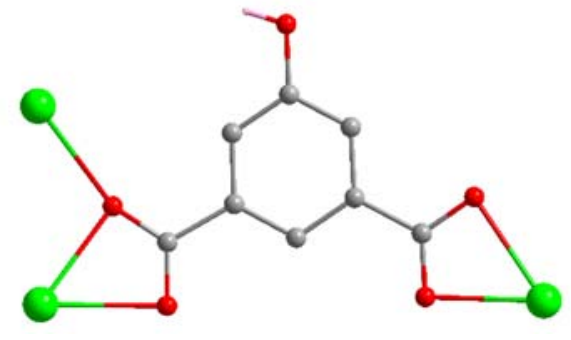

(b)

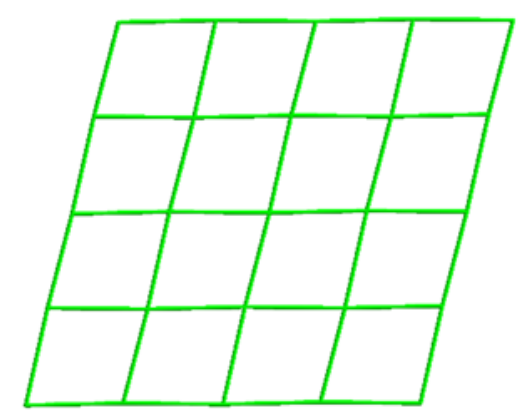

(d)

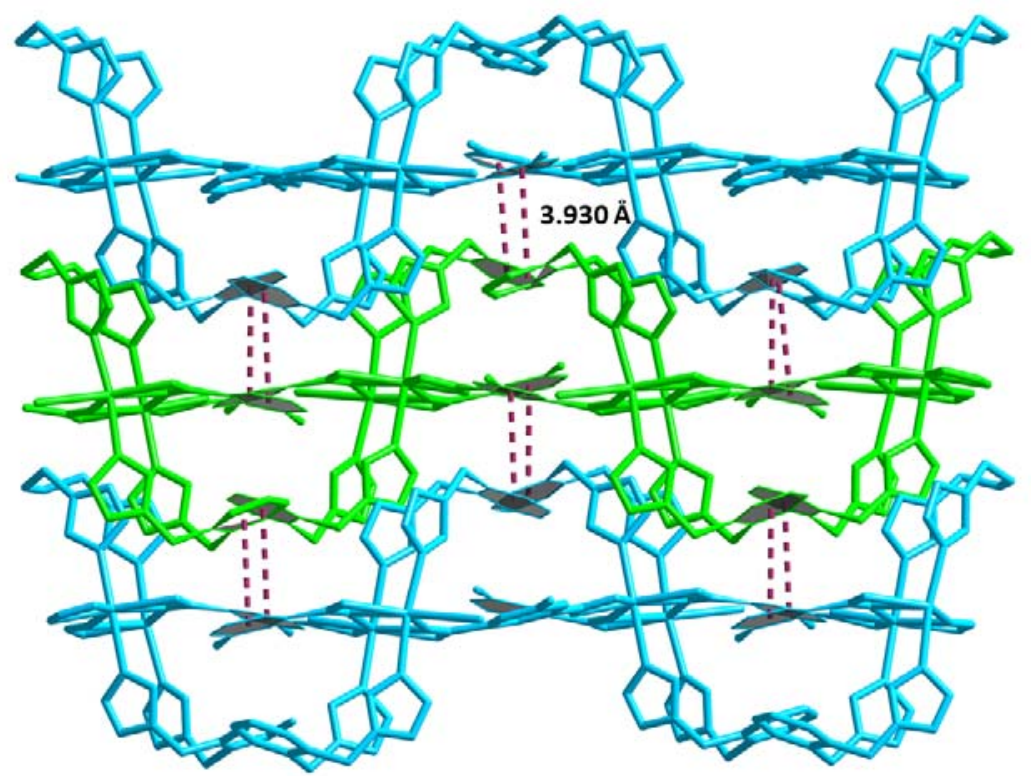

(e)

Figure 2. (a) The coordination environment of the $\mathrm{Cd}^{\mathrm{II}}$ ion in complex 2 (symmetry codes: \#1 $-1-X$, $\left.\frac{1}{2}+\mathrm{Y},-1 / 2-\mathrm{Z}\right) ;(\mathbf{b})$ The coordination mode of the 5-hipa ligand; (c) The 2D layered structure; (d) The sql topology of the complex 2; (e) The 3D supramolecular structure by $\pi \cdots \pi$ interactions (green, Cd; blue, $\mathrm{N}$; red, O; gray, C; pink, H). 


\subsection{Crystal Structures of $\left\{\mathrm{Zn}_{2}(1,2-\mathrm{Bimb})(\mathrm{L})\left(\mathrm{CH}_{3} \mathrm{COO}\right) \cdot \mathrm{DMF} \cdot 2 \mathrm{H}_{2} \mathrm{O}\right\} n$ (3)}

Structural analysis reveals that complex 3 crystallizes in the triclinic system, $P 1$ space group. There are two $\mathrm{Zn}^{\mathrm{II}}$ ions, one $\mathrm{H}_{3} \mathrm{~L}$ anion, one 1,2-bimb ligand, one coordinated acetate anion, one free DMF molecular, and two uncoordinated water molecules in the asymmetric unit. As shown in Figure $3 \mathrm{a}$, the two $\mathrm{Zn}{ }^{\mathrm{II}}$ ions are both located in a tetrahedron coordination geometry. $\mathrm{Zn} 1$ is coordinated by two oxygen atoms from two $\mathrm{H}_{3} \mathrm{~L}$ anions, another oxygen atom from acetate anion, one nitrogen atom from one 1,2-bimb ligand. The coordination patterns of $\mathrm{Zn} 1$ and $\mathrm{Zn} 2$ are very similar except that one of the oxygen atoms is from the $\mathrm{H}_{3} \mathrm{~L}$ ligand. The $\mathrm{Zn}-\mathrm{O} / \mathrm{N}$ bond lengths fall in the range of 1.928(2)-2.011(2) $\AA$. Two $\mathrm{Zn}^{\mathrm{II}}$ ions are bridged by one carboxylates from one $\mathrm{H}_{3} \mathrm{~L}$ anion with $\mathrm{Zn} 1 \cdots \mathrm{Zn} 2$ separation of 4.6985(7) $\AA$. The large atomic radius of $\mathrm{Zn}^{\mathrm{II}}$ ion makes the deprotonated $\mathrm{H}_{3} \mathrm{~L}$ anion ligand adopt a $\mu_{3}-\eta^{1}: \eta^{1}: \eta^{1}: \eta^{1} \eta^{0}: \eta^{1}$ coordination mode (Figure $3 b$ ). The 3-connected $\mathrm{H}_{3} \mathrm{~L}$ anion liagand link the $\mathrm{Zn}^{\mathrm{II}}$ ions forming a $2 \mathrm{D}\left[\mathrm{Zn}\left(\mathrm{H}_{3} \mathrm{~L}\right)\right]_{\mathrm{n}}$ sheet (Figure 3c). The 1,2-bimb act as bridging linkers, and link neighboring 2D $\left[\mathrm{Zn}\left(\mathrm{H}_{3} \mathrm{~L}\right)\right]_{n}$ sheets together into a 3D framework (Figure 3d).

Topologically, $\mathrm{H}_{3} \mathrm{~L}$ ligand can be reduced to three-connected nodes owing to connecting five $\mathrm{Zn}^{\mathrm{II}}$ ions. $\mathrm{Zn} 1$ and $\mathrm{Zn} 2$ ions are considered as one node with six-connected, and each 1,2-bimb as the two-connected, respectively. The topology of the 3D network can be defined as a $(3,6)$-connected $\left\{4^{2} \cdot 6\right\} \cdot\left\{4^{4} \cdot 6^{10} \cdot 8\right\}-3,6 \mathrm{~T} 24$ net (Figure 3e).

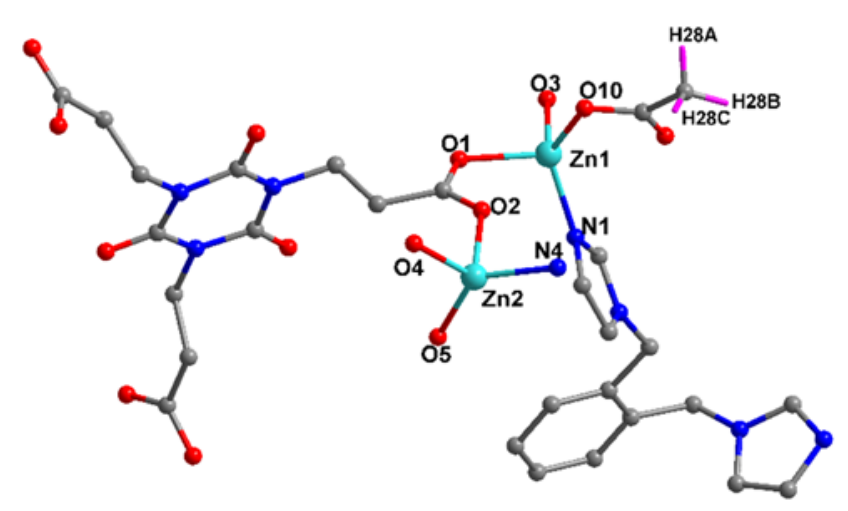

(a)

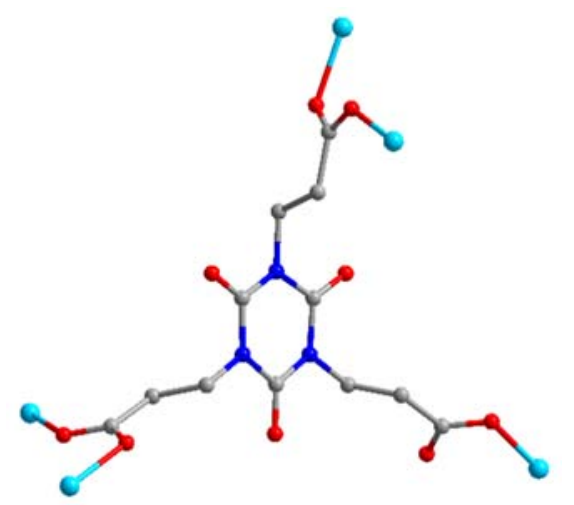

(b)

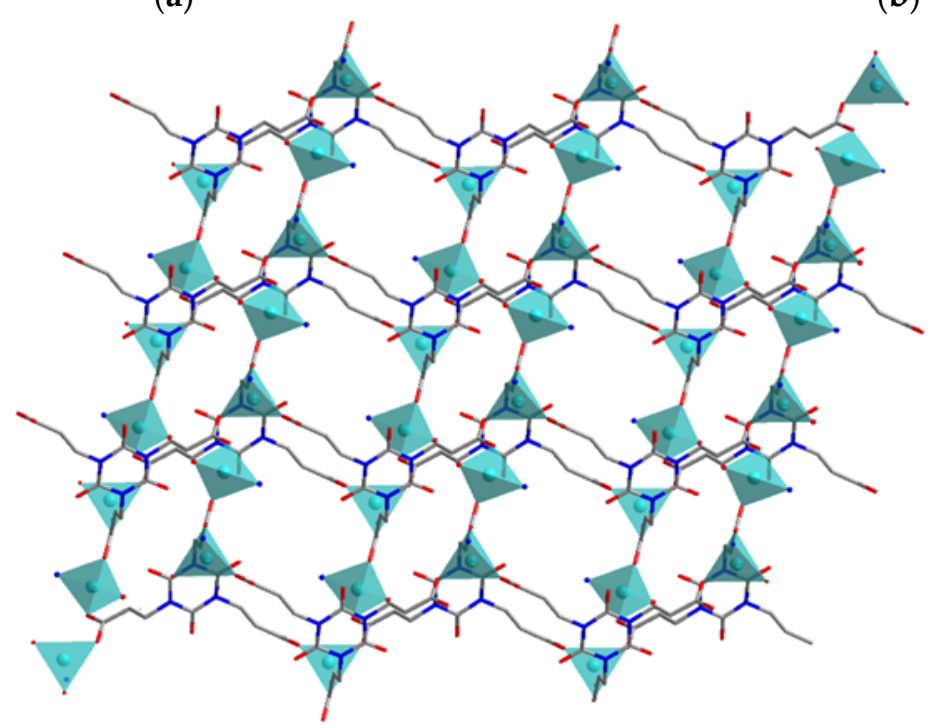

(c)

Figure 3. Cont. 


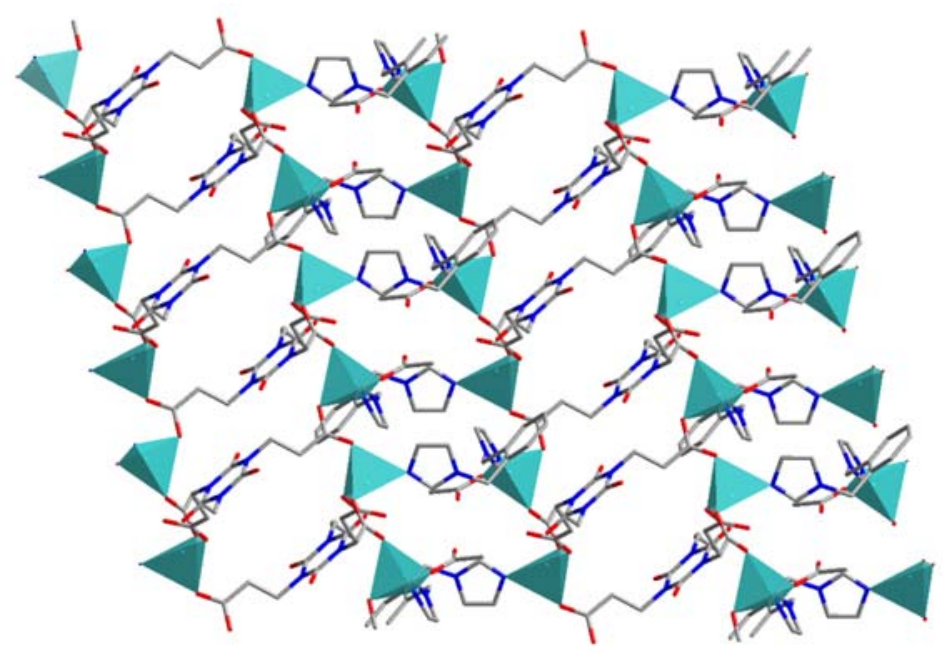

(d)

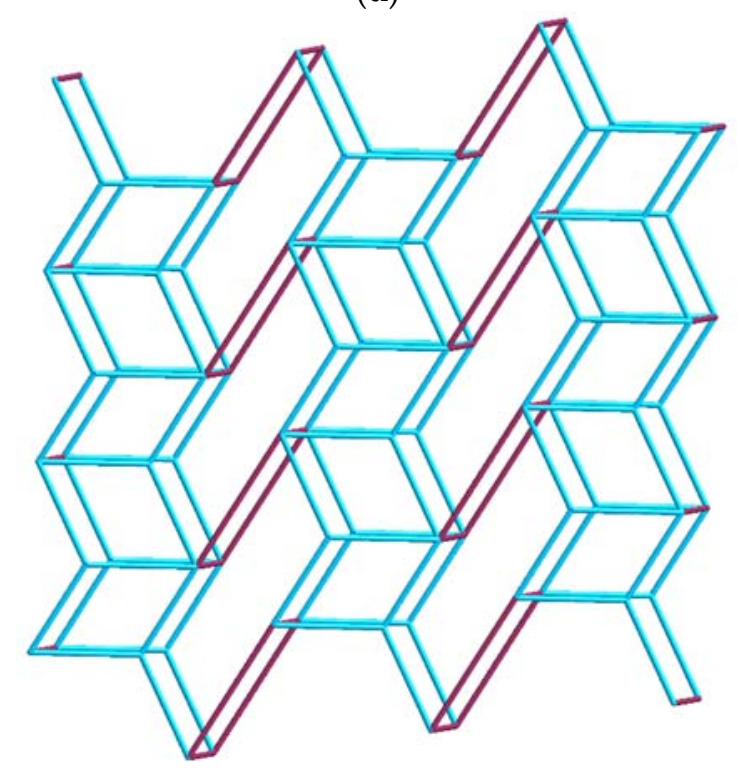

(e)

Figure 3. (a) The coordination environment of the $\mathrm{Zn}$ II ion in complex 3; (b) The coordination mode of the $\mathrm{H}_{3} \mathrm{~L}$ ligand; (c) The $2 \mathrm{D}\left[\mathrm{Zn}\left(\mathrm{H}_{3} \mathrm{~L}\right)\right]_{\mathrm{n}}$ sheet along the $c$ direction; (d) The 3D framework of the complex 3 along the $b$ direction; (e) The $\left\{4^{2} \cdot 6\right\} \cdot\left\{4^{4} \cdot 6^{10} \cdot 8\right\}-3,6 \mathrm{~T} 24$ topology of the complex 3 (cyan, Zn; blue, $\mathrm{N}$; red, O; gray, C; pink, H).

\subsection{Crystal Structures of $\{C d(1,2-B m i m b)(3-n p a)\}_{n}(4)$}

Structural anaylsis reveals complex 4 crystallizes in the monoclinic system with $P 2_{1} / n$ space group. The asymmetric unit consists of one $\mathrm{Cd}^{\mathrm{II}}$ ion, one 1,2-bmimb ligand and one 3-npa anion. As shown in Figure 4a, the central Cd ${ }^{\mathrm{II}}$ ion is five-coordinated by three oxygen atoms [Cd-O: 2.160(3)-2.365(3) $\AA]$ from two different 3-npa anions, two nitrogen atoms [Cd-N: 2.196(3)-2.207(3) $\AA$ ] originate from two 1,2-bmimb ligands, and the angle of N1-Cd1-N3 is 120.19(13) ${ }^{\circ}$. In complex 4, the two carboxyl groups of the 3-npa anion take different coordination mode. It can be expressed as $\mu_{2}-\eta^{1}: \eta^{1}: \eta^{0}: \eta^{1}$ (Figure $4 \mathrm{~b})$. The 1,2-bmimb ligand bridges the $\mathrm{Cd}^{\mathrm{II}}$ ions to generate a $\left.\mathrm{Cd}(1,2-\mathrm{bmimb})\right]_{\mathrm{n}}$ " $\mathrm{Z}$ " chain (Figure 4c). Similarly, the adjacent metal ions are connected by 3-npa anion to form one-dimensional $[\mathrm{Cd}(3-\mathrm{npa})]_{\mathrm{n}}$ chain structure (Figure $4 \mathrm{~d}$ ). These two types of single chains form a 2D layered network through cross-cutting (Figure 4e). 
Topologically, if the central $\mathrm{Cd}^{\mathrm{II}}$ ions are considered as 4-connected nodes and each 1,2-bmimb or 3-npa viewed as 2-connected spacer, complex 4 can be predigested as a $2 \mathrm{D}$ sql topology with a point symbol of $\left\{4^{4} \cdot 6^{6}\right\}$ (Figure $4 \mathrm{f}$ ). The inter-sheet $\pi \cdots \pi$ interactions between different imidazole rings act as glue to assemble the adjacent sheets in an -ABA-fashion resulting in a 3D supramolecular framework (Figure 4g).

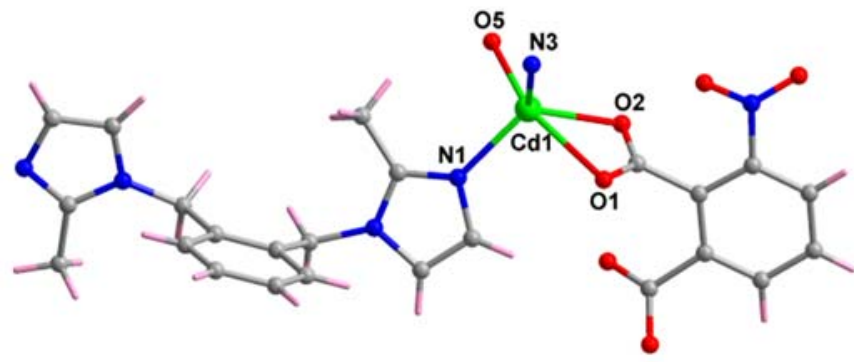

(a)

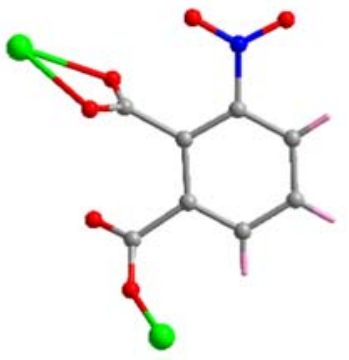

(b)

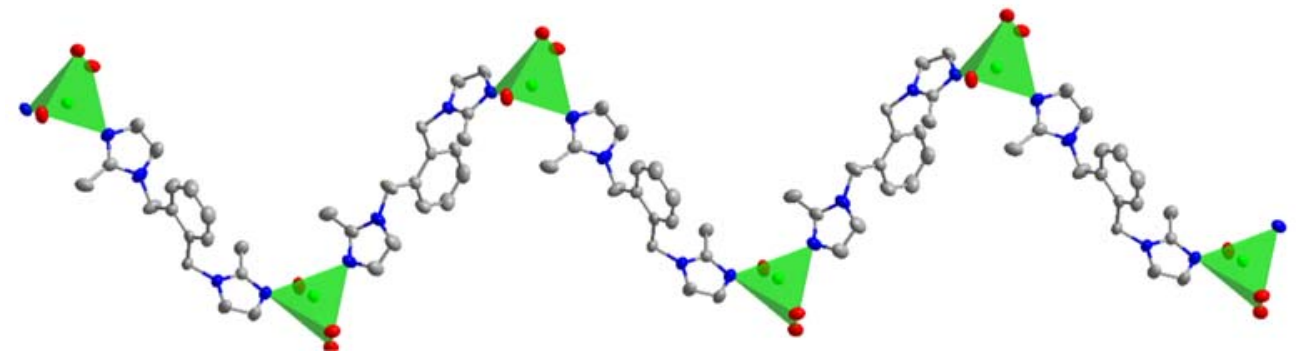

(c)

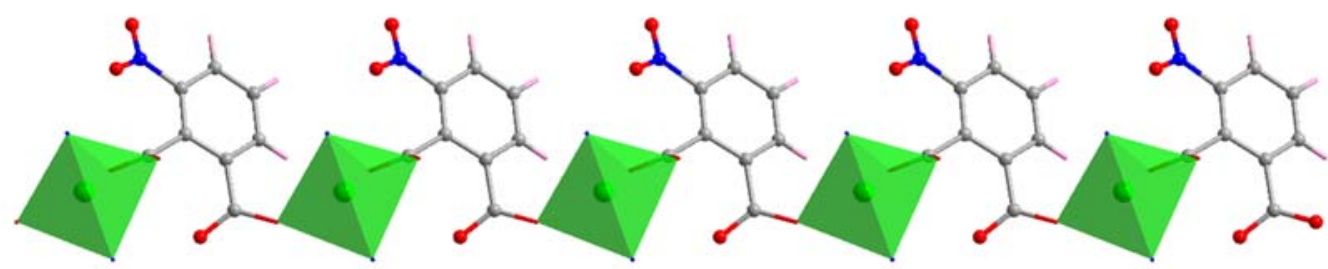

(d)

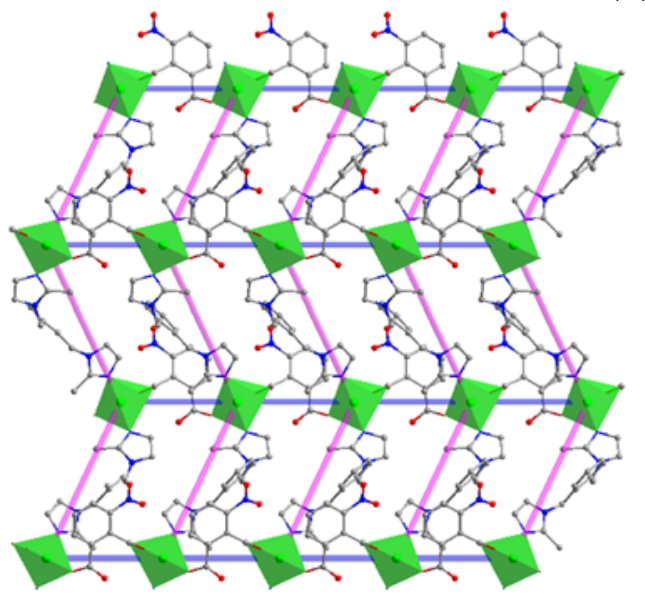

(e)

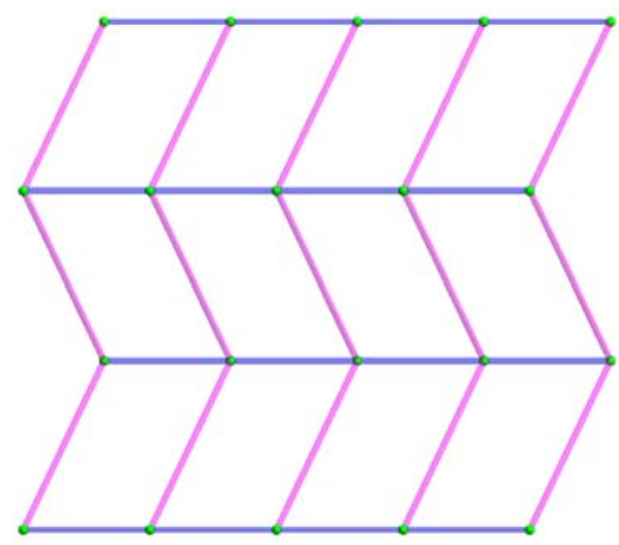

(f)

Figure 4. Cont. 


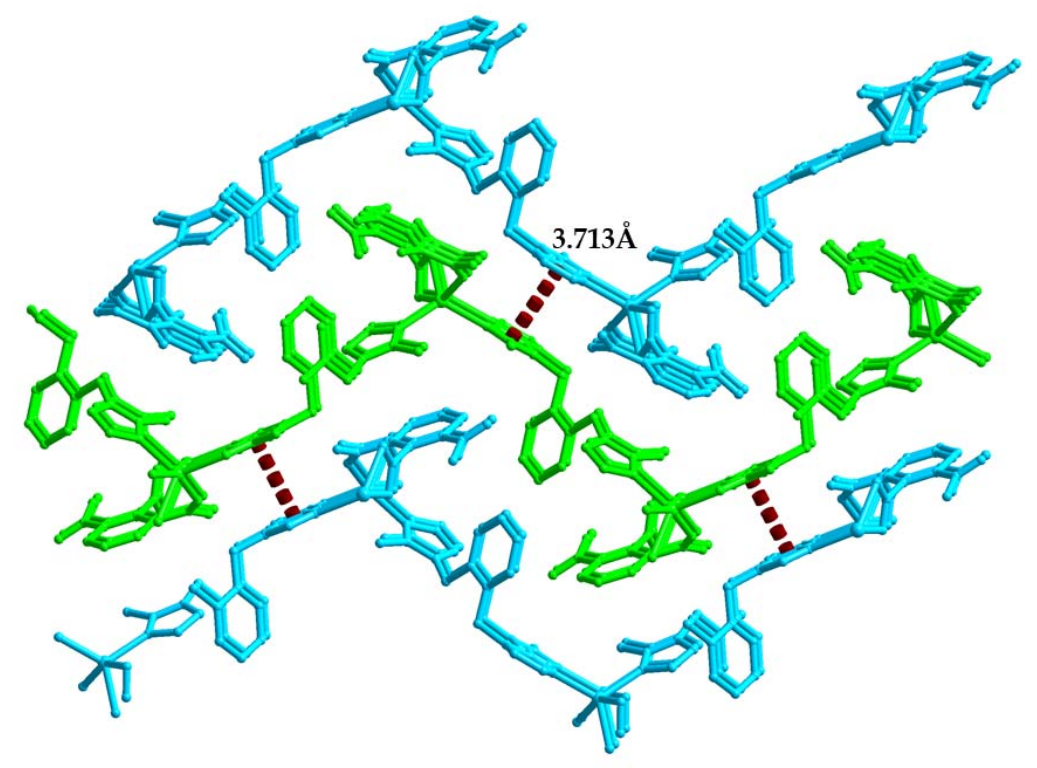

$(\mathrm{g})$

Figure 4. (a) The coordination environment of the $\mathrm{Cd}^{\mathrm{II}}$ ion in complex 4; (b) The coordination mode of the 3-npa ligand; (c) The 1D [Cd(1,2-bmimb)]n " $Z$ " chain; (d) The 1D [Cd(3-npa)]n chain structure; (e) The 2D layered structure; (f) The sql topology of the complex 4; (g) The 3D supramolecular structure by $\pi \cdots \pi$ interactions (green, $\mathrm{Cd}$; blue, $\mathrm{N}$; red, $\mathrm{O}$; gray, $\mathrm{C}$; pink, $\mathrm{H}$ ).

\subsection{Structure Discussion}

It is well known that carboxyl groups of different substitution positions or different substituents have a significant influence in terms of structure and function [31-33]. Regarding 1,2 and 4, the three kinds of dicarboxylate (para-substituted in 1, meta-substituted in 2, ortho-substituted in 4) with different coordination fashions and steric hindrances result in distinct architectures, respectively (Scheme 2). However, the structural analysis of complex 1,2 and 4 shows that the introduction of different substituents $\left(-\mathrm{NH}_{2},-\mathrm{OH},-\mathrm{NO}_{2}\right)$ has no effect on the formation of the final structure. Ignoring the effect of substituents, Complex 1,2 and $\mathbf{4}$ form a sql topology from dicarboxylate ligands with different substitution positions. As ancillary ligands, carboxylic acid ligands play an important linking role in the formation of structures.

Moreover, the primary ligand is indispensable in forming the structure. In the structures of $\mathbf{1}$ and 2, the primary ligand connects adjacent metals to form a bimetallic node, which is of great significance for the formation of a three-dimensional supramolecular structure. The $\pi \cdots \pi$ interaction between the primary and ancillary ligands reinforces the stability of the structure. In complex 4, the primary ligands not only connect the metal nodes to form a $1 \mathrm{D}$ " $\mathrm{Z}$ " chain, but also form a $\pi \cdots \pi$ stacking with adjacent primary ligands to build up a three-dimensional supramolecular structure.<smiles></smiles><smiles>[M]OC(=O)c1cc(N)c(C(O[M])O[M])cc1N</smiles><smiles>[M]OC(=O)c1cccc([N+](=O)[O-])c1C(=O)O[M]</smiles><smiles>[X][M]OC(=O)c1cc(O)cc(C(=O)O[M])c1</smiles>

Scheme 2. The diverse coordination modes of auxiliary ligands of complexes 1, 2 and 4. 


\subsection{X-ray Power Diffraction Analysis and Thermal Analysis}

The PXRD patterns were obtained at room temperature to confirm that the crystal structures are truly representative of the bulk samples in the solid state. For complexes 1-4, the peak positions of the experimental PXRD patterns closely match the simulated one based on the single-crystal X-ray date, demonstrating the high phase purity of all complexes (Figures S1-S4).

To study the stabilities of CPs, thermogravimetric (TGA) analysis of complexes 1-4 were carried out under $\mathrm{N}_{2}$ atmosphere from 30 to $600^{\circ} \mathrm{C}$ (Figure 5). In the care of complex 1 , the weight loss of $3.71 \%$ from 100 to $150{ }^{\circ} \mathrm{C}$ is attributed to the loss of lattice water molecules (calc. 3.5\%). The decomposition of the organic ligands starts at $200{ }^{\circ} \mathrm{C}$, leaving a remaining residue of $\mathrm{ZnO}$ (obsd: $16.1 \%$, calcd.: $15.7 \%$ ). For complex 2, the lattice water molecules decompose around $110^{\circ} \mathrm{C}$. And then the organic ligands of the polymers begin to pyrolyze. Ultimately leads to thermal decomposition and produces $\mathrm{CdO}$ residues. For 3 , the weight loss $12.6 \%$ occurs at $220^{\circ} \mathrm{C}$, which conforms to the loss of free DMF and $\mathrm{H}_{2} \mathrm{O}$ molecules (calcd.: $12.4 \%$ ) followed by decomposition of the polymers. The final residue is $\mathrm{ZnO}$. The TGA curve of 4 indicates it is stable up to about $210^{\circ} \mathrm{C}$, and then it begins to decompose upon further heating, leaving a remaining residue of $\mathrm{CdO}$ (obsed: $22.7 \%$, calcd.: $21.8 \%$ ).

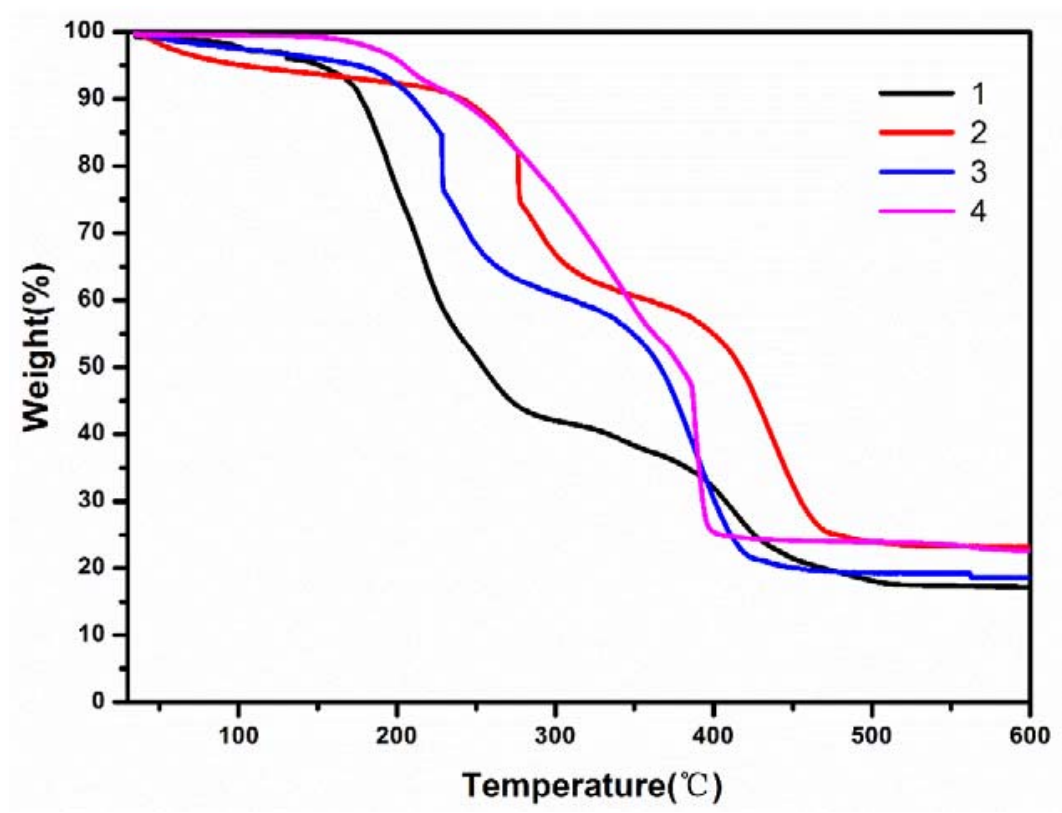

Figure 5. TGA curves for complexes 1-4.

\subsection{Photoluminescence Properties}

In general, the coordination polymers of $\mathrm{d}^{10}$ transition metal centers have been displayed photoluminescence application in luminescent materials and photochemical sensors [34-37]. Meanwhile, the luminescence properties are affected by the coordination pattern of organic ligands and different metal ions. The fluorescence properties of complexes 1-4, free 1,2-bimb and 1,2-bmimb ligand have been examined in the solid state at room temperature, as shown in Figure 6. The 1,2-bimb and 1,2-bmimb ligands display photoluminescent emissions at 483 and $447 \mathrm{~nm}$ upon excitation at $300 \mathrm{~nm}$, which may be attributed to $\pi^{*} \rightarrow \pi$ transition. Under similar excitation condition, complexes 1-4 exhibit intense emission bands at $483 \mathrm{~nm}$ for 1, $464 \mathrm{~nm}$ for 2, $438 \mathrm{~nm}$ for 3, and $442 \mathrm{~nm}$ for 4, respectively. The measured luminescence quantum yields are $10.2 \%$ for $\mathbf{1}, 15.9 \%$ for $\mathbf{2}, 12.4 \%$ for 3 and $5.7 \%$ for 4 . These broad emissions of complexes 1-4 could be regarded as arising from IL (intraligand) transitions or with the admixture of IL and MLCT (metal-to-ligand charge transfer) characters [38-41]. 


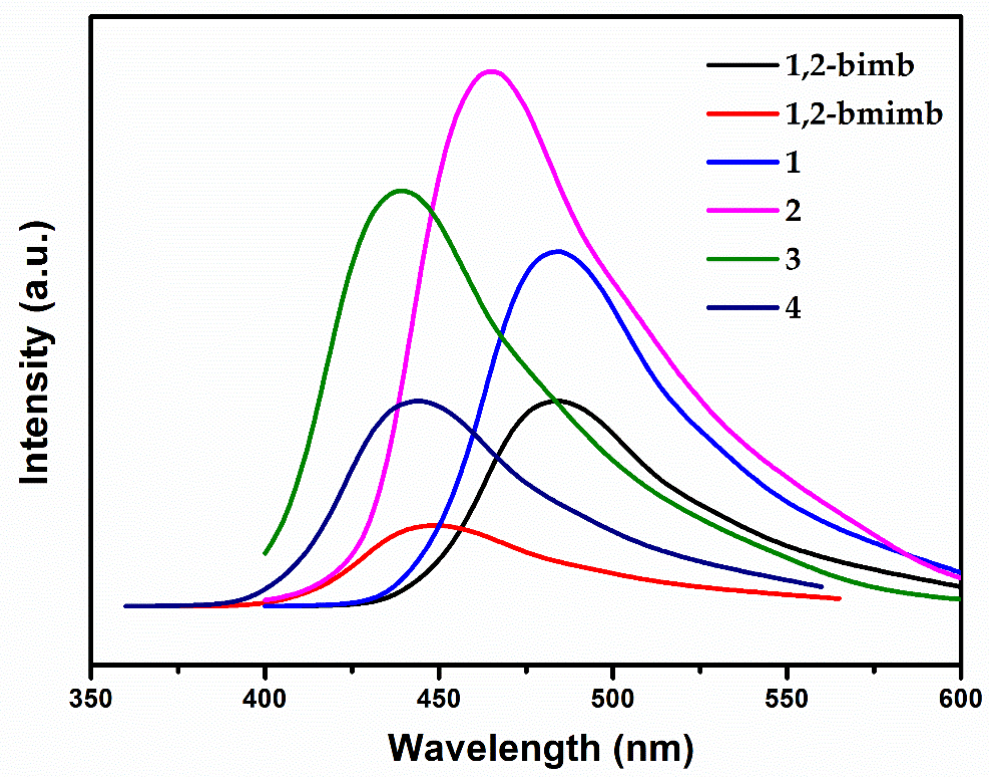

Figure 6. Photoluminescence of free ligand complexes 1-4.

\section{Conclusions}

In summary, four coordination polymers based on the mixed ligand system have been synthesized and characterized. These complexes show fascinating 2D and 3D structures. The structural diversities of the complexes indicate that the primary and auxiliary ligands show remarkable effects on the formation of the final structures. Complexes 1, 2 and 4 exhibit the same 2D sql topology network, which further constructs a 3D supramolecular framework through $\pi \cdots \pi$ stacking interactions. Complex 3 shows a $3 \mathrm{D}\left\{4^{2} \cdot 6\right\} \cdot\left\{4^{4} \cdot 6^{10} \cdot 8\right\}-3,6 \mathrm{~T} 24$ topology net. Furthermore, photoluminescence measurements reveal that complexes 1-4 are potential photochemical materials, due to their intense luminescence emission. Meanwhile, this work prompted us to obtain more CPs by using a reliable synthetic route using the mixed ligand.

Supplementary Materials: The following are available online at http://www.mdpi.com/2073-4352/8/6/236/s1, Figure S1: The PXRD data of 1; Figure S2: The PXRD data of 2; Figure S3: The PXRD data of 3; Figure S4: The PXRD data of 4; Table S1: Selected bond distances $(\AA)$ and angles $\left(^{\circ}\right)$ for 1; Table S2: Selected bond distances $(\AA)$ and angles $\left({ }^{\circ}\right)$ for 2; Table S3: Selected bond distances $(\AA)$ and angles $\left(^{\circ}\right)$ for 3; Table S4: Selected bond distances $(\AA)$ and angles $\left(^{\circ}\right)$ for 4 .

Author Contributions: K.L. and L.D. conceived and designed the experiments; K.L. performed the experiments; Y.Z. and S.J. analyzed the data; L.W. supervised the work. All the authors have contributed to manuscript revision.

Acknowledgments: This work was supported by the National Natural Science Foundation of China (No. 21601103, 21571112 and 51572136), the Natural Science Foundation of Shandong Province, China (No. ZR2016BP04), the Scientific and Technical Development Project of Qingdao (No. 17-1-1-78-jch) and the Taishan Scholars Program.

Conflicts of Interest: The authors declare no conflict of interest.

\section{References}

1. Eduardo, G.Z.; Ilich, A.I. $\mathrm{CO}_{2}$ capture under humid conditions in metal-organic frameworks. Mater. Chem. Front. 2017, 1, 1471-1484.

2. Liu, K.; Li, X.; Ma, D.X.; Han, Y.; Li, B.Y.; Shi, Z.; Wang, L. A microporous yttrium metal-organic framework of an unusual nia topology for high adsorption selectivity of $\mathrm{C}_{2} \mathrm{H}_{2}$ and $\mathrm{CO}_{2}$ over $\mathrm{CH}_{4}$ at room temperature. Mater. Chem. Front. 2017, 1, 1982-1988. [CrossRef]

3. Chen, F.L.; Bai, D.J.; Wang, Y.; Jiang, D.H.; He, Y.B. A family of ssa-type copper-based MOFs constructed from unsymmetrical diisophthalates: Synthesis, characterization and selective gas adsorption. Mater. Chem. Front. 2017, 1, 2283-2291. [CrossRef] 
4. Lide, O.A.; Tim, W.; Sun, X.H.; Freek, K.; Jorge, G. Metal organic frameworks as precursors for the manufacture of advanced catalytic materials. Mater. Chem. Front. 2017, 1, 1709-1745.

5. Zhang, J.Y.; Shi, J.X.; Chen, L.Y.; Jia, Q.X.; Deng, W.; Gao, E.Q. N-donor auxiliary ligand-directed assembly of CoII compounds with a 2,2'-dinitro-biphenyl-4,4'-dicarboxylate ligand: Structures and magnetic properties. CrystEngComm 2017, 19, 1738-1750. [CrossRef]

6. Ma, D.X.; Li, B.Y.; Zhou, X.J.; Zhou, Q.; Liu, K.; Zeng, G.; Li, G.H.; Shi, Z.; Feng, S.H. A dual functional MOF as a luminescent sensor for quantitatively detecting the concentration of nitrobenzene and temperature. Chem. Commun. 2013, 49, 8964. [CrossRef] [PubMed]

7. Hu, Z.C.; Deibert, B.J.; Li, J. Luminescent metal-organic frameworks for chemical sensing and explosive detection. Chem. Soc. Rev. 2014, 43, 5815-5840. [CrossRef] [PubMed]

8. Li, H.W.; Feng, X.; Guo, Y.X.; Chen, D.D.; Liu, R.; Ren, X.Q.; Jiang, X.; Dong, Y.P.; Wang, B. A malonitrile-functionalized metal-organic framework for hydrogen sulfide detection and selective amino acid molecular recognition. Sci. Rep. 2014, 4, 4366. [CrossRef] [PubMed]

9. Du, L.Y.; Shi, W.J.; Hou, L.; Wang, Y.Y.; Shi, Q.Z.; Zhu, Z. Solvent or temperature induced diverse coordination polymers of silver(I) sulfate and bipyrazole systems: Syntheses, crystal structures, luminescence, and sorption properties. Inorg. Chem. 2013, 52, 14018-14027. [CrossRef] [PubMed]

10. Yan, X.; Yan, Z.; Zhang, Y.; Liu, W.; Tang, Y.; Tan, M. Anions make the difference: Conversion from zeroto one-dimensional structures and luminescent properties of lanthanide-based complexes. CrystEngComm 2012, 14, 4989-4996. [CrossRef]

11. Chen, M.; Wang, Z.W.; Zhao, H.; Liu, C.S. Temperature-controlled structural diversity of two Cd(II) coordination polymers based on a flexible tripodal multicarboxylate ligand. Inorg. Chem. Commun. 2014, 45, 84-88. [CrossRef]

12. Zhang, Y.; Ju, W.; Xu, X.; Lv, Y.; Zhu, D.; Xu, Y. Two novel mixed Eu $\mathrm{u}^{3+} / \mathrm{Y}^{3+} \mathrm{Ln}$ MOFs: Influence of $\mathrm{pH}$ on the topology, Eu/Y ratio and energy transfer. CrystEngComm 2014, 16, 5681-5688. [CrossRef]

13. Cepeda, J.; Beobide, G.; Castillo, O.; Luque, A.; Pérez-Yáñez, S.; Román, P. Structure-Directing effect of organic cations in the assembly of anionic In(III)/diazinedicarboxylate architectures. Cryst. Growth Des. 2012, 12, 1501-1512. [CrossRef]

14. Santanu, C.; Elahi, S.M.; Pal, A.; Das, M.C. A new set of Cd(II)-coordination polymers with mixed ligands of dicarboxylate and pyridyl substituted diaminotriazine: Selective sorption towards $\mathrm{CO}^{2}$ and cationic dyes. Dalton Trans. 2017, 46, 9901-9911.

15. Wang, X.L.; Hou, L.L.; Zhang, J.W.; Zhang, J.X.; Liu, G.C.; Yang, S. Assembly and properties of coordination polymers modulated by substituted 1,3-benzenedicarboxylates. CrystEngComm 2012, 14, 3936-3944. [CrossRef]

16. Fan, L.M.; Fan, W.L.; Li, B.; Zhao, X.; Zhang, X.T. Coligand syntheses, crystal structures, luminescence and photocatalytic properties of five coordination polymers based on rigid tetracarboxylic acids and imidazole linkers. CrystEngComm 2015, 17, 9413-9422. [CrossRef]

17. Han, Y.; Sun, L.W.; Dong, G.L.; Wang, H.L.; Li, H.J.; Wang, L. Diverse architectures of hybrid materials induced by different mixed-ligands and applications in luminescence. Inorg. Chem. Commun. 2017, 78, 37-42. [CrossRef]

18. Liu, K.; Sun, Y.Y.; Deng, L.M.; Cao, F.; Han, J.H.; Wang, L. Cu(II) coordination polymers constructed by tetrafluoroterephthalic acid and varied imidazole-containing ligands: Syntheses, structures and properties. J. Solid State Chem. 2018, 258, 24-31. [CrossRef]

19. Sheng, X.L.; Xu, D.H.; Cai, B.; Liu, J.L. Poly [[bis $\left\{\mu_{2}-1,2-b i s[(1 H\right.$-imidazol-1-yl)meth-yl]benzene $\}$ ( $\mu_{4}-9,10$-dioxo-9,10-dihydroanthracene-1,4,5,8-tetracarboxylato)dicobalt (II)] dihydrate]. Acta Crystallogr. Sect. E 2013, 69, m136. [CrossRef] [PubMed]

20. Zhang, S.S.; Chen, L.J. Poly [[ $\mu_{2}-1,2-b i s\left(1 H\right.$-imidazol-1-ylmethyl)benzene- $\left.\kappa^{2} \mathrm{O}^{1}: \mathrm{O}^{4}\right)$ zinc (II)]. Acta Cryst. 2010, $66, \mathrm{~m} 1456$.

21. Zhang, X.W.; Xing, P.Q.; Geng, X.J.; Sun, D.F.; Xiao, Z.Y.; Wang, L. Transition metal coordination polymers based on tetrabromoterephthalic and bis(imidazole) ligands: Syntheses, structures, topological analysis and photoluminescence properties. J. Solid State Chem. 2015, 229, 49-61. [CrossRef]

22. Liu, R.Q.; Zhao, N.; Yang, F.X.; Wang, A.R.; Liu, P.; An, C.X.; Lian, Z.X. Structures and enhanced third-order nonlinear optical performance of four complexes investigated by thin film Z-scan technique. Transit. Met. Chem. 2016, 41, 721-730. [CrossRef] 
23. Yan, Z.H.; Zhang, X.W.; Pang, H.D.; Zhang, Y.H.; Sun, D.F.; Wang, L. Solvothermal synthesis, crystal structure and photoluminescence properties of four $\mathrm{Cd}(\mathrm{II})$ coordination polymers with different topological structures. RSC Adv. 2014, 4, 53608. [CrossRef]

24. Zheng, T.; Cai, Z.S.; Nie, W.X.; Ren, M.; Bao, S.S.; Zhang, L.M. Modulating the microporosity of cobalt phosphonates via positional isomerism of co-linkers. CrystEngComm 2015, 17, 8926. [CrossRef]

25. Yang, J.; Ma, J.F.; Liu, Y.Y.; Ma, J.C.; Batten, S.R. A series of Cu(II) complexes based on different bis(imidazole) ligands and organic acids: Formation of water clusters and fixation of atmospheric carbon dioxide. Cryst. Growth Des. 2008, 8, 4383-4393. [CrossRef]

26. Fan, J.G.; Yee, T.; Wang, G.B.; Hanson, B.E. Syntheses, structures, and magnetic properties of inorganic-organic hybrid cobalt(II) phosphites containing bifunctional ligands. Inorg. Chem. 2006, 45, 599-608. [CrossRef] [PubMed]

27. Hoskins, B.F.; Robson, R.; Slizys, D.A.; Am, J. An infinite $2 \mathrm{D}$ polyrotaxane network in $\mathrm{Ag}_{2}(\mathrm{bix})_{3}\left(\mathrm{NO}_{3}\right)_{2}(\mathrm{bix}$ =1,4-Bis(imidazol-1-ylmethyl)benzene). Chem. Soc. 1997, 119, 2952-2953. [CrossRef]

28. Sheldrick, G.M. Program for Empirical Absorption Correction of Area Detector Data; University of Göttingen: Göttingen, Germany, 1996.

29. Sheldrick, G.M. SHELXTL, version 5.1; Bruker Analytical X-ray Instruments Inc.: Madison, WI, USA, 1998.

30. Sheldrick, G.M. SHELXL-97, PC version; University of Göttingen: Göttingen, Germany, 1997.

31. Manasi, R.; Satirtha, S.; Sukhen, B.; Sudeshna, B.; Raju, M. Systematic study of mutually inclusive influences of temperature and substitution on the coordination geometry of $\mathrm{Co}(\mathrm{II})$ in a series of coordination polymers and their properties. Cryst. Growth Des. 2016, 16, 3170-3179.

32. Wang, H.; Yi, F.Y.; Dang, S.; Tian, W.G.; Sun, Z.M. Rational assembly of Co/Cd-MOFs featuring topological variation. Cryst. Growth Des. 2014, 14, 147-156. [CrossRef]

33. Zhou, J.; Du, L.; Qiao, Y.F.; Hu, Y.; Li, B.; Li, L.; Wang, X.Y.; Yang, J.; Xie, M.J.; Zhao, Q.H. Intriguing architectures generated from 1,4-Bis(3- or 4-pyridyl)-2,3-diaza-1,3-butadiene with aromatic dicarboxylates: Syntheses, crystal structures, and properties. Cryst. Growth Des. 2014, 14, 1175-1183. [CrossRef]

34. Cui, Y.J.; Yue, Y.F.; Qian, G.D.; Chen, B.L. Luminescent functional metal-organic frameworks. Chem. Rev. 2012, 112, 1126-1162. [CrossRef] [PubMed]

35. Qiu, Y.C.; Li, Y.H.; Peng, G.; Cai, J.B.; Jin, L.M.; Ma, L.; Deng, H.; Zeller, M.; Batten, S.R. Cadmium metal-directed three-dimensional coordination polymers: In situ tetrazole ligand synthesis, structures, and luminescent properties. Cryst. Growth Des. 2010, 10, 1332-1340. [CrossRef]

36. Jiang, H.L.; Liu, B.; Xu, Q. Rational assembly of $\mathrm{d}^{10}$ metal-organic Frameworks with helical nanochannels based on flexible v-shaped ligand. Cryst. Growth Des. 2010, 10, 806-811. [CrossRef]

37. Ji, C.C.; Qin, L.; Li, Y.Z.; Guo, Z.J.; Zheng, H.G. Effect of different imidazole ancillary ligands on supramolecular architectures of a series of $\mathrm{Zn}(\mathrm{II})$ and $\mathrm{Cd}(\mathrm{II})$ complexes with a bent dicarboxylate ligand. Cryst. Growth Des. 2011, 11, 480-487. [CrossRef]

38. Wen, L.; Lu, Z.; Lin, J.; Tian, Z.; Zhu, H.; Meng, Q. Syntheses, structures, and physical properties of three novel metal-organic frameworks constructed from aromatic polycarboxylate acids and flexible imidazole-based synthons. Cryst. Growth Des. 2007, 7, 93-99. [CrossRef]

39. Lin, J.G.; Zang, S.Q.; Tian, Z.F.; Li, Y.Z.; Xu, Y.Y.; Zhu, H.Z.; Meng, Q.J. Metal-organic frameworks constructed from mixed-ligand 1,2,3,4-tetra-(4-pyridyl)-butane and benzene-polycarboxylate acids: Syntheses, structures and physical properties. CrystEngComm 2007, 9, 915. [CrossRef]

40. Wen, L.; Li, Y.; Lu, Z.; Lin, J.; Duan, C.; Meng, Q. Syntheses and Structures of Four d10 Metal-Organic Frameworks Assembled with Aromatic Polycarboxylate and bix [bix = 1,4-Bis(imidazol-1-ylmethyl)benzene]. Cryst. Growth Des. 2006, 6, 530-537. [CrossRef]

41. Zhao, X.; Wang, X.; Sun, D.; Sun, D. Novel metal-organic framework based on cubic and trisoctahedral supermolecular building blocks: Topological analysis and photoluminescent property. Cryst. Growth Des. 2012, 12, 2736-2739. [CrossRef]

(C) 2018 by the authors. Licensee MDPI, Basel, Switzerland. This article is an open access article distributed under the terms and conditions of the Creative Commons Attribution (CC BY) license (http:/ / creativecommons.org/licenses/by/4.0/). 